\title{
Toponyms' contribution to identity: The case study of Rabat (Morocco)
}

\author{
Malak Alasli \\ Department of Cartography and Geoinformatics, ELTE Ë̈tvös Loránd University, alaslima.ma@gmail.com
}

\begin{abstract}
:
Toponymy is a crucial component for cartographic representation of geographic information. Toponyms are essential building blocks of communities and identity. Place names are instruments of meaning to be attached to spaces to convert them into places. Among their functions, place names are said to be vectors of a transgenerational communication. They lift the veil on the relationship they hold with identity. They make us better understand the population's means of expression, which will shed light on the identification they attribute to themselves. This study is an analysis of the relationship between place names and identity. It advances that place name holds more meaning than just a way to indicate a place. The nature of this investigation makes it possible for using case study as a qualitative research design. To ensure more valid conclusions, multiple data collection tools were adopted. Semi-structured interviews provide more flexibility and satisfy most of the research objectives. The other instrument used is a questionnaire for the purpose of eliciting more information from the respondents. The objective is to investigate the image displayed by the place names in use. The results point to the symbolic nature of place names in the construction of identities. In this regard, they are not mere signifiers of places and markers of destination but offer insight into the imposed identity and ideology on a landscape.
\end{abstract}

Keywords: Toponymy, identity, place names

\section{Introduction}

The toponymy of a country, a region, a city, or some other geographical territory, is the set of names that designate every component of these spaces. These names are studied from various viewpoints: their origin, their meaning, the circumstances of their attribution to the places they designate, their linguistic evolution, and the way in which they are used at the different local, regional, national and international levels.

Place names are closely linked to our sense of self, that is our identity. They are not mere signifiers of places but offer insight into the underlying perspective of communities. They become carriers of something other than themselves as material extents. One could say that in principle all places have a symbolic dimension. Places are made to have a greater emotional charge than merely a location.

Socially, place names are instrumental in the development of both individual and collective identity. At the psychological level, place names invoke diverse attitudes in the minds owing to the different associations and connotations of the place names, that is their descriptive backing (Meiring, 1993). The connotation of a name points to the totality of associations which people often perform when the name is employed in a communicative interactive manner. With place names, connotation underscores the emotional overtones (onomastic associations).

To each individual is attached a set of places: place of birth, the places of origin of her/his family, the places in which she/he lived successively, the places the person frequents or frequented, but also places more imaginary or projected as the desired places of life or potential projects.

\subsection{Literature review}

Toponymy, the science of place names, is based on the search for their etymology, their meaning, and their evolution through time. Among their functions, place names are said to be vectors of transgenerational communication.

Place names are instruments of meaning to be attached to spaces in order to convert them into places. A place is therefore "a physical location imbued with meaning" (Cosgrove, 1989: 104). Rofe and Szili (2009: 362-363) advance that place names "communicate a sense of the landscape to which they are attached". According to Tuan, place names are not mere labels but also help make the world a meaningful place. "Most people take names seriously, whether they be their own, those of other people, or those of geographical places." (Tuan 1991, p. 688)

The notion of identity is variedly defined. Oxford English Dictionary (OED V: 19) defines identity as, 1) "The quality or condition of being the same in substance, 
composition, nature, or in particular qualities under consideration; absolute or essential sameness; oneness", 2) "The sameness of a person or a thing at all times or in all circumstances; the condition or fact that a person or a thing is itself and not something; individuality or personality".

\subsection{Social identity}

Place names hold the power of constructing social identities. This complex process is accomplished through two concepts: place identity and place attachment.

\subsubsection{Place identity}

Place identity displays the self-image of the immediate community by projecting how people relate with places. Individuals alter it to reflect who they think they are and whom they aspire to be.

Carter (1987) asserts that place naming symbolically transforms space into a place. Therefore, a place is a space bearing meaning.

Proshansky (1978: 155) defines place-identity as:

...those dimensions of self that define the individual's personal identity in relation to the physical environment by means of a complex pattern of conscious and unconscious ideas, feelings, values, goals, preferences, skills, and behavioral tendencies relevant to a specific environment.

Place identity is a convoluted process of marking identity where individuals indicate that they belong to a particular place through names. (Helleland, 2009; Korpela, 1989).

\subsubsection{Place attachment}

People associate emotional and symbolic meanings to places and hence develop personal attachments.

Place attachment denotes the special feelings or the affective bond between people and specific places (Hildago \& Hernandez, 2001). It analyzes the concept of human-place bonding taking into consideration "the meanings humans associate with the physical environment". (Kyle, Graefe, Manning \& Bacon, 2004: 213).

Place attachment is concerned with "understanding the subjective, emotional, and symbolic meanings associated with natural places and the personal bonds or attachments people form with specific places and landscapes" (Williams \& Vaske, 2003:1, cited in Kyle, et al. 2004: 213).

This concept advocates the idea of feeling at home. Jordan (2012) postulates that place names support emotional ties; they are an essential element of feeling at home. Besides, Pfukwa (2012) premises that place names are an indispensable component of the nation's overall identity.

\subsection{Levels of identity}

There are two levels of identity: individual and collective identity. Pfukwa and Viriri (2009) propose that individual identity has a "persistent selfsameness" while the group identity has "collective sameness". Both group and individual identities are significant in the discussion of the projection of the self and how the individual or the group perceives itself.
Pfukwa (2007: 43) asserts:

The self has an image it perceives and seeks to project: this is the projected identity. The recipient or the public have their own perceptions, and this is what Joseph (2004) calls receptive processes in identity.

Simmel (1997) cited in Jaworski and Thurwol (2009: 6) submits:

We create our identities in part through the process of geographical imagining, the locating of self in space, claiming the ownership of specific places, or by being excluded from them, by sharing space and interacting with others....

This shows that place names hold more meaning than just naming. Uttering a place name is associated with an entire abstract background. It plays as instrument that is used to include (for in-group members) or to exclude (for outgroup members). Place names are significant in describing people in terms of how they belong to specific groups and places. (Helleland, 2009; 2012a)

\subsection{Descriptive backing}

This aspect can also be seen in the light of denotations and connotations. Akmajian, Demers, Farmer and Harnish (1984: 240) posit that: "denotations are events or things in the world (or groups of them); what words and phrases denote are the things and events that the words correctly indicate, name, or describe". Whereas it is, as defined by O'Grady (1996: 233), "the set of associations that a word's use can evoke". In simple words, denotation is the literal meaning, whereas connotation is the sum total of the associations that people attach to a word.

A distinction between denotation and connotation in Semantics is important in demonstrating the descriptive backing of names. Descriptive backing helps to show how names convey connotative meanings.

With place names, connotation underscores the emotional overtones or as Nicolaisen (1978) calls it "onomastic associations". The latter is also known, according to onomastic theory, as descriptive backing.

Meiring (1993:274) advances that descriptive backing: Amounts to the collective content of all conventional beliefs and connotations attached to a name. It [...] has a subjective content as it is based on individual experience and knowledge about a place, person or object bearing a name.

Basso (1988: 103) makes a similar observation saying that: Because of their inseparable connection to specific localities, place names may be used to summon forth an enormous range of mental and emotional associations associations of time, of history, of events, of personal and social activities, of oneself, and stages in one's life.

\section{Methodology}

\subsection{Area of study}

Figures 1 to 4 present some necessary information on the cities in question. The localization, the cities' distance from each other, their area, and population are all included in this research to allow for an extensive understanding of the environment. 


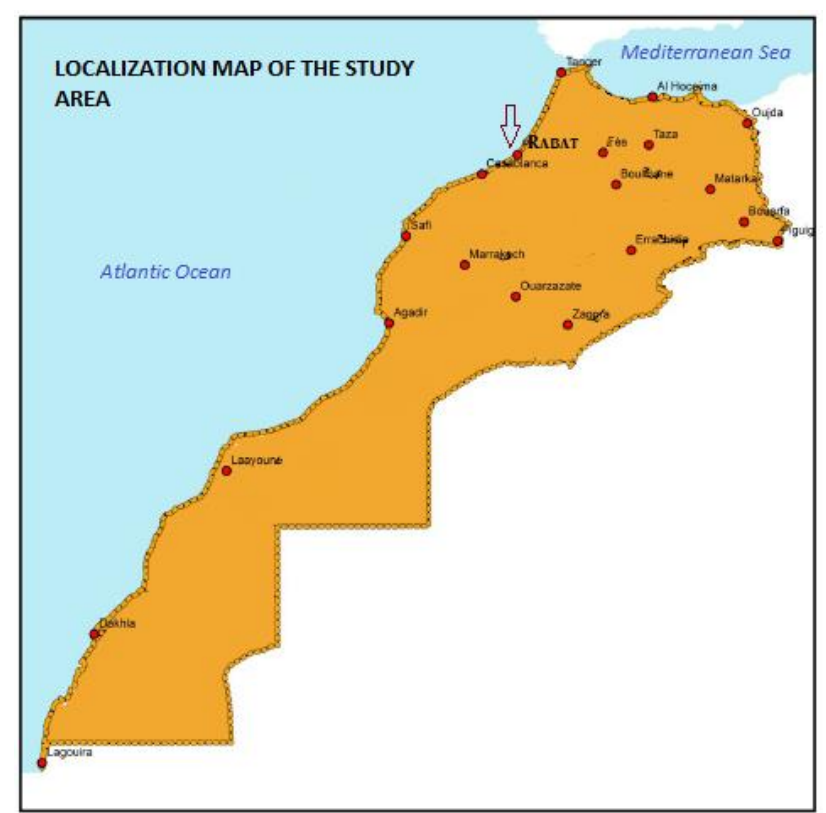

Figure 1. Location of the study area

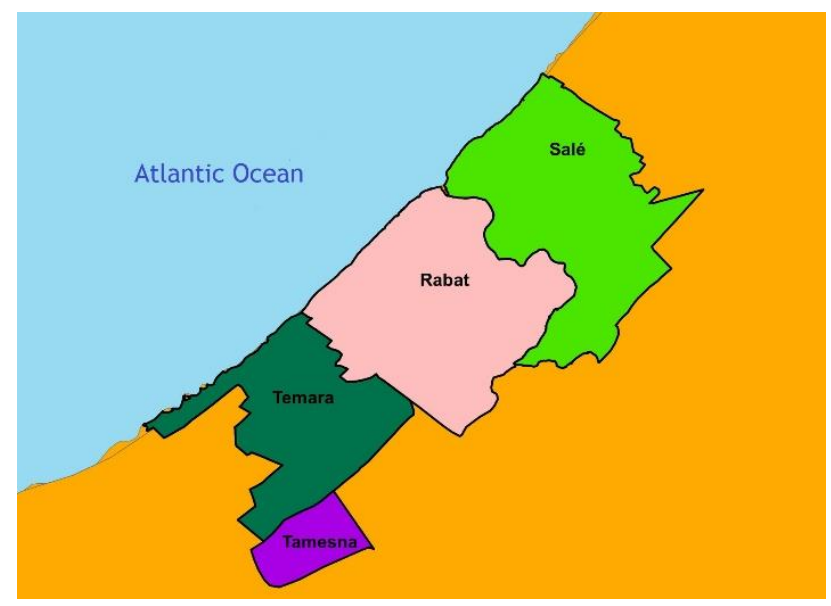

Figure 2. The area of the target cities

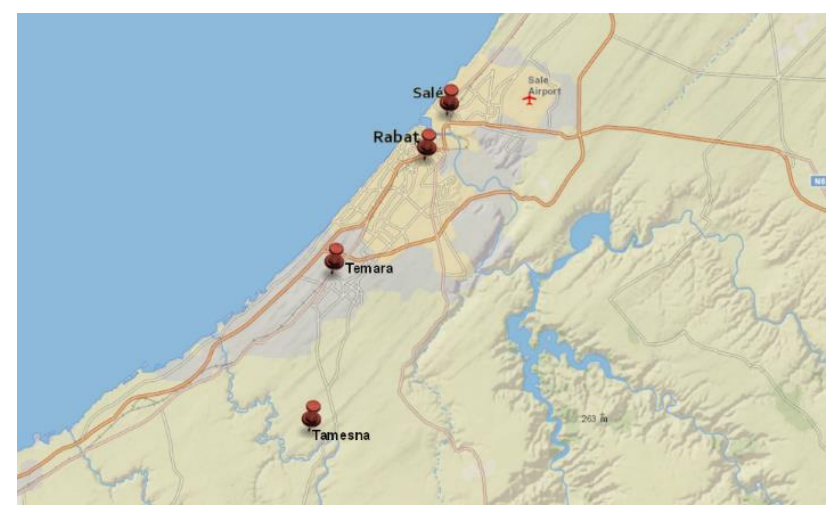

Figure 3. The distance between the cities

\section{Population}

1655753

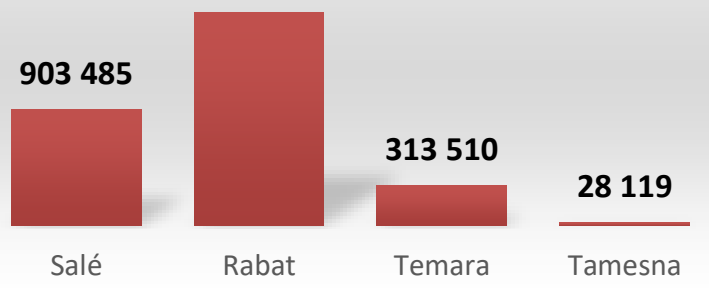

Figure 4. Population according to Word Population Review 2019

\subsection{Background on the cities Rabat}

It is located on the Atlantic coast. The Almohads established the present capital of Morocco in the middle of the twelfth century. During the era of the Almohads, the city was known as a historical and cultural radiance. It was converted into a fortified fortress to protect its armies. Rabat acquired the title "Ribatu 1-Fath" meaning "stronghold of victory", from which it derives its current name.

\section{Salé}

Salé is an ancient Moroccan city near the capital of Rabat. It is located on the edge of the Atlantic Ocean, on the right bank (north) of river Bouregreg.

This name has been known since ages. The name "سلا" (Salé) emerged in the Roman era, where it derived its name from "شالة" (chellah) and it was known by the Carthaginians as "Shalat". When the Romans occupied it, they called it Sala Colonia. Moreover, The word "شالة" (Shala) in the old and modern Berber language, Aramaic and Phoenician means "plenitude".

\section{Temara}

The coastal city of Temara was founded in the 12th century AD during the reign of the Almohads and extends over an area of $30 \mathrm{~km}^{2}$. It is close to Rabat and is only $70 \mathrm{~km}$ away from Casablanca. Temara used to be a sleeping place for workers in Rabat, Casablanca and other nearby cities with almost no activity or economic movement, but has witnessed a significant change in the last years.

\section{Tamesna}

Tamesna is a new Moroccan semi-built city, located between Temara, and Sidi Yahia Zaer, and is 11 kilometers away from Temara. It was founded to absorb the additional population in Rabat and Temara, and to house the slum dwellers of the neighboring localities in social housing. The word Tamesna means "the plain" in the Berber language.

\subsection{Data collection}

This study is an analysis of the relationship between place names and identity. It advances that place name holds more meaning than just a way to indicate a place. The nature of the study makes it possible for using case study as a qualitative research design. Creswell (2009: 13) 
defines case study as "a strategy of inquiry in which the researcher explores in depth a program, event, activity, process, or one or more individuals". Although a case is mainly associated with a person, it in fact can be done on a group, on an institution, on an innovation, on a decision, on a service, on a program and on many other things. Typically, a case study makes use of multiple sources and techniques in the process of gathering data (Yin, 2009).

Inhabitants of the neighboring cities of the capital of Morocco, namely Salé, Temara, and Tamesna are the purposively chosen subjects to serve as data. The aim is to explore how place names are closely tied to identity. To elicit a neutral perception, none of the respondents lived in Rabat before which will eliminate the possibility of referring to it as the city of residence. The gender distribution of the sample was $42 \%$ males and $58 \%$ females.

To ensure more valid conclusions, multiple data collection tools were adopted. Semi-structured interviews provide more flexibility and satisfy most of the research objectives, especially the associative meanings that place names evoke. They also shed light on some of the reasons why people associate themselves with a certain place name rather than another. The other instrument used is a questionnaire for the purpose of eliciting more information from the respondents. Most respondents speak classical Arabic and French; however, preference was given to interviews in the local dialect to allow for the full expression of respondents' feelings and understandings.

For a more relaxed environment, the interviews started with a "a non-threatening open-ended question that gets the interviewee talking and helps to put them at ease" (Kelly, 2006: 299). To many researches, naturallyoccurring talk is the most reliable and fruitful data gathering technique. Migdadi (2003) argues that naturallyoccurring talk has the "advantage of reflecting the actual use of language". Therefore, no strict pattern was followed when starting the conversation; questions depended on the age, gender, and location. The conversations focused more on the question of where do you live rather than where you are from. All interviews took place in various locations in Rabat, and a total of 84 interviews were taken as Data. The goal was to investigate whether their first immediate answer to "where do you live?" would be Rabat.

The 84 interviewees were given a questionnaire, and a total of 63 responses were received, giving a response rate of $75 \%$. The questionnaire was comprised of three sections. Section 1 consisted of demographic attributes like gender and educational level. In section 2, respondents were queried to designate the place of inhabitance and explain what the place name means. Section 3 consisted of questions related to people's perception of that place. In addition, they were also asked to indicate what city they relate to and why they feel so. The questionnaire also included a field where respondents were free to express their views on a particular aspect, allowing for personal opinions to be expressed in the respondent's own words.

There is an unconscious attempt by interviewers of directing the interviewee towards giving certain types of responses. In turn, this affects the objectivity of the interviewees as they tend to give answers, they think the interviewer expects not their actual views. To avoid this disadvantage, the real reason behind the conversations was not first explained to them. It was later that the purpose was revealed to the interviewees who were asked for their consent to use the gathered information. Furthermore, anonymity and confidentiality are the two ethical points that this study took into consideration.

\section{Discussion}

All participants do not and have never lived in Rabat. The conversations had the intention of eliciting information on what place name they will use, and among the 84 participants, 59 people cited Rabat as a place of inhabitance. A profound analysis was favored to attempt an understanding of the matter. Those most inclined to refer to Rabat as their place of residence are people under 45 (69\%). Other demographic characteristics, mainly gender, were of little importance, as they reported no distinct effect on the results. It is also important to note that there exists no significant difference in the usage of the language between the participants.

Of significance to this study is the observation that place name has a symbolic meaning in addition to their apparent referential role. Names serve not only as markers of destination but also participate in the symbolic construction of identity. During one of the conversations held with a middle-aged man from Temara, a quite interesting point was stated. When I questioned why he referred to Rabat as his place of inhabitance, he replied "just look at the name, tamara! It says it all" (translated). I noticed the phonetic manipulation and pointed that Temara "تَمَارة" is a Hebrew feminine name meaning Palm (palm tree) and has a root of "تَرَ " which in Standard Arabic means dates (the fruit of the date palm tree). He replied: "we're Moroccans and that's Tamara" (translated). Place names derive their connotative meanings, partly from the language itself, partly from the environment. The articulation of "Tamara" which in Moroccan dialect means hardship or a tiring task instead of Temara entails there exists more layers of meaning. Consequently, place names unveil meanings that are discrepant from what they designate in the Arabic context but unique to the Moroccan setting.

Moreover, aside from the names' significance in the Arabic language context, place names display additional functions that characterize the sociolinguistic background. To illustrate, the word "sala" in Moroccan Arabic, depending on the setting and the people, could be comprehended as done, finished, or over. During one of the conversations, a participant was asked to describe the place name Salé in one word. His answer was "النهاية" (the end) stating that "when a movie ends, we say 'sala' the film, and that's the end" (translated). His representation was also based on a real-life occurrence and routine. As he works in Rabat, he explained that at the end of the day you leave your work exhausted and head home, much to your surprise, find yourself stuck for another hour traffic in Salé and that's the 
$\mathrm{KO}$ - the end. The place names become a window that reflects the relationship between language and realities obtaining in society. The place name constructs its meaning out of lived experience. Additionally, place names play a significant role in the creation of a positive or negative sense of place - the way we perceive places. Its sense arises from personal occurrences and delimits how individuals view, interpret and interact with their world.

According to Adegbija (1988), utterances can be understood according to three layers of meaning. He proclaims the layers as the primary, the secondary, and the tertiary layer. The primary level addresses the apparent or literal level of meaning where an interpretation of the linguistic components and the prosodic functions such as intonation, tone, stress, and rhythm of expression is required. At the secondary layer, the focal point is the connotative or figurative level of meaning. Lastly, the third level of meaning requires an understanding of the diverse perspectives of the socio-cultural environment where an expression is made. Hence, the primary layer can decode most of the senses of words, whereas some aspects can only be apprehended by going through the secondary layer (connotative).

Therefore, deciphering the speaker's intention using pragmatics by emphasizing the ways in which the former use language (place names) in specific contexts demonstrates that places are made to have greater emotional charge than merely a location. Proper names are a way to identify an individual, a place or an organization. When asked about our name, the logical response would be to provide the name we were given at birth. Thus, if place names were just a way to locate a place, the reasonable answer to "where do you live" shouldn't include a different place.

In other words, pragmatics puts forward that people can perform acts [speech acts] by using language similar to how they can conduct physical acts. Austin's (1975) efforts endeavored to indicate how speakers can intend far more than what their words say. In his speech act theory, he introduced three terms: locution which is the literal meaning of words uttered or the determinate 'sense' and reference, illocution as the intended meaning or force behind the words, and perlocution points to the effect the utterance might have on the hearer.

The example of: "I live in Rabat"; The locutionary act specifies a location, the illocutionary act serves as a force of identification, and perlocutionary act influences the addressee.

- The locutionary act: I live in the city of Rabat.

- Illocutionary act: I associate myself with the inhabitants of the capital rather than the inhabitants of the neighboring cities.

- Perlocutionary act: The effect that this utterance has on the hearer can change from one individual to another. The effects can take the form of attitudes, perceptions, imaginations, feelings or emotions. There exist several associations to the name that people make whenever they hear it.
To try to understand some of the associations that the use of the place name Rabat can evoke, I asked several participants about what comes to their mind when they hear it. Their responses varied but certain phrases were repeated. The results can be classified into two main classes; characteristics of the city, and characteristics of the people who live in the city (Table 1).

\begin{tabular}{|c|c|c|}
\hline & $\begin{array}{l}\text { Phonetic } \\
\text { transcription }\end{array}$ & $\begin{array}{l}\text { Attempted } \\
\text { translation into } \\
\text { English } \\
\end{array}$ \\
\hline \multirow{10}{*}{$\begin{array}{l}\text { Characteristics } \\
\text { of the people } \\
\text { who live in } \\
\text { the city }\end{array}$} & wld lmdi:na & The city boy \\
\hline & $\begin{array}{l}\text { wld Sa?ila/ } / i \\
\text { ben fi ћaza }\end{array}$ & $\begin{array}{l}\text { comes from a } \\
\text { known family }\end{array}$ \\
\hline & $\begin{array}{l}\text { xdam/ } \\
\text { mu:wadaf }\end{array}$ & An employee \\
\hline & $\begin{array}{l}\text { Myeser Slih } \\
\text { lah }\end{array}$ & rich \\
\hline & lijaqa & A snob \\
\hline & nas mfeуu:la & Busy people \\
\hline & $\begin{array}{l}\text { nas lim }\{a \\
\text { lhadata } \\
\text { ?u:lSawlama }\end{array}$ & $\begin{array}{l}\text { Modernity and } \\
\text { Globalization }\end{array}$ \\
\hline & $\begin{array}{l}\text { Kari } ? u: \\
\text { Jaliban ma/i } \\
\text { rbat }^{\zeta} i\end{array}$ & $\begin{array}{l}\text { Someone who is } \\
\text { renting a house } \\
\text { there and probably } \\
\text { not originally from } \\
\text { Rabat }\end{array}$ \\
\hline & $\begin{array}{l}\text { Labsin } \\
\text { costume } \\
\text { (French word) } \\
\end{array}$ & Wearing suits \\
\hline & 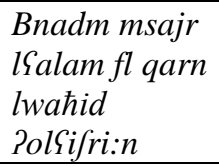 & $\begin{array}{l}\text { People who keep } \\
\text { up with the world } \\
\text { in the } 21 \text { th century }\end{array}$ \\
\hline \multirow{9}{*}{$\begin{array}{l}\text { Characteristics } \\
\text { of the city }\end{array}$} & Hassan & $\begin{array}{l}\text { The neighborhood } \\
\text { of Hassan }\end{array}$ \\
\hline & Lbћar & The beach \\
\hline & Tram & tramways \\
\hline & $\begin{array}{l}\text { Stationnement } \\
\text { (French word) }\end{array}$ & Parking lot \\
\hline & ktret lbolis & The police \\
\hline & $\begin{array}{l}\text { Lmdi:na/bab } \\
\text { lhed }\end{array}$ & The old medina \\
\hline & Lqesar & The royal palace \\
\hline & Swiqa & $\begin{array}{l}\text { a shopping area in } \\
\text { the old medina }\end{array}$ \\
\hline & $\begin{array}{l}\text { Fin kajnin } \\
\text { lzamiSat }\end{array}$ & $\begin{array}{l}\text { Where there are } \\
\text { Universities }\end{array}$ \\
\hline
\end{tabular}

Table 1. The participants' response

For foreigners, Rabat is the capital of Morocco, but for Moroccans, there exist a number of associations that this place name elicits. These associations are unique to the Moroccan socio-cultural context. 
A participant's perception of Tamesna, the city where she lives, testifies to her will of excluding herself from a specific group. She says, "I do not relate with people there" (translated) while pointing out that she does not associate with that particular setting. Similarly, her attachment to Rabat suggests a projection of the landscapes that she believes best describes her. Consequently, the place name holds a significant contribution to the identity of the individual and it plays as instruments that are used to include (for in-group members) or to exclude (for out-group members). Therefore, their answer was a way of identifying themselves with another group. Place names are significant in describing people according to how they belong to specific groups and places. Hence, toponymy holds more meaning than just naming. When uttering a place name, a whole subconscious background is linked to it. Place names are intimately associated with our sense of self, that is our identity.

One cannot help but observes that places resonate with meanings. Besides the place names' function as indicators of specific localities, they also carry implications that people sense and decipher proceeding from their duties, background, and inspirations. Different answers were provided by the respondents to explain the reason of choosing Rabat, for instance, "I'm planning to move there", "I work and spend more time there", "That's where I feel I belong to", "If you get to know me, you'll understand that I'm more Rbati (people from Rabat) than Slawi (people from Salé)". This perceived ability to turn from one group to another can be elaborated in the light of "social identity", where the individual acknowledges a belonging to a certain social group. The place name becomes meaningful and significant to people.

Another interesting finding is the pride of some of the people who live in Salé, when asked "where do you live?" they answered with "I'm Slawi (from Salé)" rather than "I live in Sale". They expressed their pride by stating that the first demonstrations for independence against the French first started in Salé. They showed a "tribal" sense of belonging. Moreover, most of the respondents who did not refer to Rabat as their residency were from Salé.

The results noticeably answer the question of the role of places in the individual process of identity formation. Admittedly, when people were asked what place name thoroughly defines them, their responses ranged from places with the most accumulation of memories and personal experience to their aspirations and self-image. The place name acted as a significant factor of identification. Identity and place are inseparable as the way one represents the self is expressed by particular aspects and attributes of that specific place.

\section{Conclusion and recommendations}

The objective of this work was to demonstrate the importance of place names as markers of identity. The data is in the form of 84 interviews that seemed relevant to the purpose of the study, along with a number of questionnaires. The obtained results attest that place names, in addition to their apparent referential role, also participate in the symbolic construction of identity. The place name has additional meanings other than its literal sense, and acquires its connotations, partly from the language itself, partly from the environment. The study also showed that place names display some senses that are unique to the Moroccan context, in other words, they become a window that reflects the relationship between language and realities obtained in society. The analysis observed that the respondents' choice of Rabat was dependent on various factors; the various associations that the place name evokes in the Moroccan socio-cultural context, the projection of people's experience, responsibilities, and motivations on the specific localities, and its notable contribution to the identity of the individual where it acts as instrument that is used to include (for ingroup members) or to exclude (for out-group members). Place names are significant in representing people according to how they belong to specific groups and places. Hence, toponymy holds more meaning than just naming as place names are closely related to our sense of self, that is our identity.

\section{Acknowledgements}

I would like to thank Dr. Gábor Gercsák (ELTE Eötvös Loránd University) for support and useful discussions.

\section{Appendix}

List of phonetic symbols:

\begin{tabular}{|c|c|}
\hline $\begin{array}{c}\text { IPA } \\
\text { (consonants) }\end{array}$ & Letter(s) \\
\hline $\mathrm{b}$ & ب ب \\
\hline d & د \\
\hline$d_{3} \sim 3$ & ج \\
\hline f & ف \\
\hline $\mathrm{h}$ & o \\
\hline$\hbar$ & $\tau$ \\
\hline $\mathrm{j}$ & ي \\
\hline $\mathrm{k}$ & 5 \\
\hline 1 & J \\
\hline $\mathrm{m}$ & 5 \\
\hline $\mathrm{n}$ & ن \\
\hline$q$ & ق \\
\hline $\mathrm{r}$ & $J$ \\
\hline $\mathrm{S}$ & س \\
\hline $\int$ & ش \\
\hline $\mathrm{t}$ & ة ت \\
\hline $\mathrm{t}^{\mathrm{S}}$ & b \\
\hline $\mathrm{W}$ & 9 \\
\hline $\mathrm{x}$ & $\dot{\tau}$ \\
\hline
\end{tabular}

\begin{tabular}{|c|c|}
\hline $\begin{array}{c}\text { IPA } \\
\text { (vowels) }\end{array}$ & Letter(s) \\
\hline a: : : a: & ايه \\
\hline e: & ي \\
\hline i: & $و$ \\
\hline $\mathrm{u}:$ &
\end{tabular}




\begin{tabular}{|c|c|}
\hline $\mathrm{V}$ & $\dot{\varepsilon}$ \\
\hline $\mathrm{Z}$ & j \\
\hline ؟ & $\varepsilon$ \\
\hline$?$ & ؤ ئ إ آ أ \\
\hline
\end{tabular}

\section{References}

Adegbija, Efurosibina. 1988. My friend, where Is Anini: Decoding the Meaning of Utterances. Journal of Pragmatics 12.151-60.

Akmajian, A.,Demers, R. A., Farmer, A. K. \& Harnish, R. M. 1984. Linguistics: An Introduction to Language and Communication. MIT Press: Cambridge.

Austin, J. L. (John Langshaw) (1975). How to do things with words. Urmson, J. O., Sbisà, Marina. (2nd ed.). Cambridge, Mass.: Harvard University Press.

Basso, K. 1988. "Speaking with names": Language and landscape Among the Western Apache. Cultural Anthropology 3 (2): 99-130.

Carter, P. 1987. The Road to Botany Bay. London: Faber and Faber.

Cosgrove D, 1989, "Power and place in the Venetian territories", in The Power of Place. Bringing Together Geographical and Sociological Imaginations Eds J A Agncw, J S Duncan (Unwin Hyman, Boston, MA).

Creswell, J. W. (2009) Research Design. (3rd Edition) London, Sage.

Helleland, B. 2009. Place Names as Identity Markers. In Ahrens, W. Embleton, S. \& Lapierre, A. (eds.) Names in Multi-lingual, Multi-cultural and Multi-ethnic Contact. Toronto: York University. 501-510.

Hildago, M. C. \& Hernandez, B. H. 2001. Place Attachment: Conceptual and Empirical Questions. Journal of Environmental Psychology 21: 273.

Horsman, S. (2006). The Politics of Toponyms in the Pamir Mountains. Area, 38(3), 279-291. Retrieved from http://www.jstor.org/stable/20004545.

Jaworski, A. \& Thurlow, C. 2009. Introducing Semiotic Landscapes. In Jaworski, A. \& Thurlow, C. (eds.) Semiotic Landscapes: Language, Image and Space. London: Continuum.1-40.

Jordan, P. 2012. Place Names as Ingredients of Spacerelated Identity. Names and Identities 4 (2).

Kelly, K. 2006(b). Lived Experience and Interpretation: The Balancing Act in Qualitative Analysis. In Terre Blanche, M., Durrheim, K. \& Painter, D. (eds.) Research in Practice: Applied Methods for the Social Sciences. Cape Town: University of Cape Town Press.

Korpela, K. M. 1989. Place-identity as a Product of SelfRegulation. Journal of Environmental Psychology 9: 241-256.
Kyle, G., Graefe, A., Manning, R \& Bacon, J. 2004. Effects of Place Attachment on User's Perceptions of Social and Environmental Conditions in a Natural Setting. Journal of Environmental Psychology 24: 213225.

Meiring, B. A. 1993. The Syntax and Semantics of Geographical Names. In Hattingh, P.S., Kadmore, N., Raper, P.E. \& Booysen I. (eds.) United Nations Group of Experts on Geographical Names Training Course in Toponymy for Southern Africa. Pretoria: Department of Geography, University of Pretoria. 269-288.

Migdadi (2003) argues that naturally-occurring talk has the" advantage of reflecting the actual use of language".

Nicolaisen, W.F.H. 1978. Are there Connotative Names? Names 3: 136-152.

OED $=$ The Oxford English Dictionary. I-XII. Oxford/London 1970. At the Clarendon Press.

Pfukwa, C. \& Viriri, A. 2009 From Wasu to Samaz. Proceedings for ALASA Conference.

Pfukwa, C. 2007. The Function and Significance of War Names in the ZimbabweanConflict (1966- 1978). PhD Thesis. Pretoria: University of South Africa.

Pfukwa, C. 2012. Taking to the Streets: An Onomastic Analysis of Selected Suburbs of the City of Harare, Zimbabwe. Nomina Africana 26

Proshansky, H.M. (1978). The city and self-identity. Environment and Behavior, 10,147-169.

Rofe, M.W. \& Szili, G. 2009. Name Games 1: Place Names as Rhetorical Devices. Landscape Research 34 (3): 361-370.

Tuan, Y- F. 1991. Language and the Making of Place. A Narrative-Descriptive Approach. Annals of the Association of American Geographers 81 (4): 684-696.

Yin, Robert, Case Study Research: Design and Method (4th ed.) (UK: Sage, 2009).

http://worldpopulationreview.com/countries/moroccopopulation/ 